\title{
PENGARUH KECERDASAN EMOSIONAL, INDEPENDENSI, DAN PROFESIONALISME TERHADAP PENGAMBILAN KEPUTUSAN AUDITOR PADA KANTOR AKUNTAN PUBLIK PADANG
}

\author{
Agussalim M ${ }^{1}$, Netti Herawati ${ }^{2}$, Titi Darmi ${ }^{3}$ \\ Universitas Ekasakti ${ }^{1,2}$, \\ Universitas Muhammadiyah Bengkulu ${ }^{3}$ \\ titi.harmadi@gmail.com ${ }^{3}$
}

\begin{abstract}
ABSTRAK
Penelitian ini bertujuan untuk mengetahui apakah berpengaruh kecerdasan emosional, independensi, dan profesionalisme auditor terhadap pengambilan keputusan pada Kantor Akuntan Publik Padang baik secara parsial maupun secara simultan. Metode dalam penelitian ini menggunakan analisis data regresi linier berganda dan determinasi. Hasil penelitian ini didapatkan data bahwa nilai koefisien regresi kecerdasan emosional sebesar 0,379 dengan nilai signifikan sebesar 0,094 , hal ini menunjukkan bahwa nilai signifikan 0,094 > alpha 0,05 maka kecerdasan emosional tidak berpengaruh positif terhadap pengambilan keputusan auditor, nilai koefisien regresi independensi sebesar - 0,097 dengan nilai signifikan sebesar 0,519, hal ini menunjukkan bahwa nilai signifikan sebesar 0,519 > alpha 0,05 maka independensi tidak berpengaruh bertanda negatif terhadap pengambilan keputusan auditor, sedangkan nilai koefisien regresi profesionalisme sebesar 0,526 dengan nilai signifikan sebesar 0,009, hal ini menunjukkan bahwa nilai signifikan sebesar 0,009 < alpha 0,05 maka profesionalisme berpengaruh positif terhadap pengambilan keputusan auditor. Simpulan penelitian ini bahwa kecerdasan emosional, independensi, dan profesionalisme auditor secara simultan berpengaruh signifikan terhadap terhadap pengambilan keputusan pada Kantor akuntan Publik Padang baik secara parsial maupun simultan.
\end{abstract}

Kata Kunci: Independensi, Kecerdasan Emosional, Pengambilan Keputusan, Profesionalisme.

\begin{abstract}
This study aims to determine whether the emotional intelligence, independence, and professionalism of the auditors in decision making at the Padang Public Accountant Office either partially or simultaneously. The method in this research uses multiple linear regression data analysis and determination. The results of the research show that the intelligence coefficient of intelligence is 0.379 with a significant value of 0.094, this indicates that the significant value is 0.094> alpha 0.05, so emotional intelligence has no positive effect on the auditor's decision, the regression coefficient value is -0.097 with a significant value of 0.519., this shows that the significant value is 0.519> alpha 0.05, so the independence does not have a negative effect on auditor decision making, while the professionalism regression coefficient value is 0.526 with a significant value of 0.009 , this indicates that the significant value is $0.009<$ alpha 0, 05 then professionalism has a positive effect on auditor decision making. The conclusions of this investigation are emotional intelligence, independent, and auditor professionalism simultaneously have a significant effect on decision making at the Padang Public Accounting Firm either partially or simultaneously.
\end{abstract}

Keywords: Emotional Intelligence, Decision Making, Independence, Professionalism. 


\section{PENDAHULUAN}

Di era globalisasi, baik di dunia usaha, perbankan, pemerintahan maupun masyarakat, masalah menjadi semakin kompleks sehingga menuntut adanya perkembangan berbagai disiplin ilmu. Akuntansi merupakan disiplin ilmu yang memegang peranan penting khusunya dalam bidang ekonomi dan sosial karena setiap pengambilan keputusan yang bersifat keuangan harus berdasarkan informasi akuntansi.

Informasi akuntansi yang dihasilkan oleh auditor dalam mengambil suatu keputusan harus memiliki kecerdasan intelektual atau yang lazim dikenal sebagai Intelligence Quotient (IQ). Selain IQ, manusia juga masih memiliki dimensi kecerdasan lainnya, diantaranya yaitu: kecerdasan emosional atau Emotional Quotient (EQ) dan kecerdasan spiritual atau Spiritual Quotient (SQ). Memasuki abad ke-21, legenda IQ sebagai satu-satunya tolok ukur kecerdasan yang juga sering dijadikan parameter keberhasilan manusia, digugurkan oleh munculnya konsep EQ .

Auditor dalam mengambil keputusan haruslah independen. Independen berarti bahwa di dalam setiap pengambilan keputusan sudah sesuai dengan kebijakan dan prosedur yang ditetapkan agar kantor akuntan publik memperoleh keyakinan yang layak, dimana seorang auditor tidak dipengaruhi oleh pihak manapun. Keputusan yang diambil berdasarkan fakta dan bukti selama penugasan yang terdapat di lapangan. Sedangkan, obyektif adalah suatu kualitas atau nilai atas jasa yang diberikan anggota. Prinsip obyektivitas mengharuskan anggota bersikap adil, tidak memihak, jujur, serta bebas dari benturan kepentingan atau berada di bawah pengaruh pihak lain. Alasan diperlakukannya perilaku professional pada setiap profesi adalah kebutuhan akan kepercayaan publik terhadap kualitas jasa yang diberikan profesi.

Independensi merupakan salah satu komponen etika yang harus dijaga oleh akuntan publik. Independen berarti akuntan publik tidak mudah dipengaruhi, karena ia melaksanakan pekerjaan untuk kepentingan umum. Akuntan publik tidak dibenarkan memihak kepentingan siapapun. Auditor berkewajiban untuk jujur, tidak hanya kepada manajemen dan pemilik perusahaan, namun juga kepada kreditur dan pihak lain yang meletakkan kepercayaan atas pekerjaan akuntan publik. Sikap mental independen tersebut meliputi independen dalam fakta (in fact) maupun dalam penampilan (in appearance). Tudingan pelanggaran independen dalam penampilan sering terjadi. Setidaknya terdapat dua hal penyebab pelanggaran ini yaitu: pertama, kantor akuntan publik melakukan multi service pada klien yang sama dan kedua, tidak ada batasan lamanya kantor akuntan publik yang sama melakukan audit pada klien yang sama. Oleh karena itu, ada dorongan kuat bagi auditor untuk bertindak dengan profesionalisme yang tinggi. Kepercayaan pemerintah dan masyarakat terhadap dunia usaha atau jasa yang diberikan para pelaksana bisnis, khususnya auditor. Untuk itu menuntut adanya kecerdasan emosional, independensi dan profesionalisme auditor yang bersangkutan.

Profesional berarti bertanggung jawab untuk berperilaku yang lebih dari sekedar memenuhi tanggung jawab yang dibebankan kepadanya. Persyaratan profesional yang dituntut dari auditor independen adalah orang yang memiliki pendidikan dan pengalaman berpraktik sebagai auditor independen. Dalam meningkatkan profesionalisme seorang auditor harus terlebih dahulu memahami dirinya sendiri dan tugas yang akan dilaksanakan serta selalu meningkatkan dan mengendalikan dirinya dalam berhubungan dengan pengguna jasa audit.

Penelitian ini merupakan gabungan dari penelitian Faisal (2012), tentang Pengaruh Kompetensi, Independensi dan Profesionalisme terhadap Kualitas Audit dengan Kecerdasan Emosional Sebagai variabel moderasi (survei pada Kantor Akuntan Publik di Indonesia). Hasil penelitian menunjukkan bahwa variabel kompetensi, independensi dan profesionalisme secara bersama berpengaruh terhadap kualitas audit. Namun secara parsial hanya variabel kompetensi yang berpengaruh positif signifikan terhadap kualitas audit, 
dan penelitian Herry (2006), meneliti tentang pelaksanaan etika profesi Independensi, integritas dalam pengambilan keputusan akuntan publik (auditor). Hasilnya menyatakan bahwa independensi, integritas dan objektivitas tidak memiliki pengaruh yang signifikan dalam pengambilan keputusan akuntan publik.

Dalam penelitian Faisal melihat pengaruh indenpedensi terhadap kualitas audit tetapi peneliti saat ini ingin melihat pengaruh independensi tersebut terhadap pengambilan keputusan auditor dan menambah dua variabel lagi yaitu kecerdasan emosional dan profesional. Penelitian Herry (2006) menyatakan independensi tidak mempengaruhi dalam pengambilan keputusan. Untuk itu menurut peneliti sendiri independensi berpengaruh terhadap pengambilan keputusan auditor.

Kecerdasan emosional, independensi dan profesionalisme yang dimiliki oleh seorang auditor mempengaruhi auditor dalam mengambil keputusan. Menurut Arens, Alvin A (2004) keputusan auditor adalah merupakan suatu proses yang tersusun baik dalam memutuskan laporan audit apa yang tepat untuk diterbitkan pada serangkaian kondisi tertentu.

\section{Konsep Kecerdasan Emosional}

Menurut Goleman (2002) "Kecerdasan emosional merupakan kemampuan emosi yang meliputi kemampuan untuk mengendalikan diri, memiliki daya tahan ketika menghadapi suatu masalah, mampu mengendalikan impulse, memotivasi diri, mampu mengatur suasana hati, kemampuan berempati dan membina hubungan dengan orang lain"

Kecerdasan emosi dapat menempatkan emosi seseorang pada porsi yang tepat, memilah kepuasan dan mengatur suasana hati. Koordinasi suasana hati adalah inti dari hubungan sosial yang baik. Apabila seseorang pandai menyesuaikan diri dengan suasana hati individu yang lain atau dapat berempati, orang tersebut akan memiliki tingkat emosionalitas yang baik dan akan lebih mudah menyesuaikan diri dalam pergaulan sosial serta lingkungannya.

Sejalan dengan itu Mayer dan Salovey dalam Yanti (2013) mendefinisikan bahwa: "Kecerdasan emosi sebagai suatu kecerdasan sosial yang berkaitan dengan kemampuan individu dalam memantau baik emosi dirinya maupun emosiorang lain, dan juga kemampuannya dalam membedakan emosi dirinya dengan emosi orang lain, dimana kemampuan ini digunakan untuk mengarahkan pola pikir dan perilakunya".

Robert dan Cooper dalam Kusuma (2011), mengungkapkan bahwa kecerdasan emosi adalah kemampuan merasakan, memahami dan secara efektif menerapkan daya dan kepekaan emosi sebagai sumber energi, emosi, koneksi dan pengaruh yang manusiawi. Individu yang mampu memahami emosi individu lain, dapat bersikap dan mengambil keputusan dengan tepat tanpa menimbulkan dampak yang merugikan kedua belah pihak. Emosi dapat timbul setiap kali individu mendapatkan rangsangan yang dapat mempengaruhi kondisi jiwa dan menimbulkan gejolak dari dalam. Emosi yang dikelola dengan baik dapat dimanfaatkan untuk mendukung keberhasilan dalam berbagai bidang karena pada waktu emosi muncul, individu memiliki energi lebih dan mampu mempengaruhi individu lain. Segala sesuatu yang dihasilkan emosi tersebut, bila dimanfaatkan dengan benar dapat diterapkan sebagai sumber energi yang diperlukan untuk menyelesaikan tugas, mempengaruhi orang lain dan menciptakan hal-hal baru.

Kecerdasan emosi tidak ditentukan sejak lahir tetapi dapat dilakukan melalui proses pembelajaran. Ada beberapa faktor yang mempengaruhi kecerdasan emosi individu menurut Goleman (2002), yaitu:

\section{Pertama Lingkungan keluarga.}

Kehidupan keluarga merupakan sekolah pertama dalam mempelajari emosi. Peran serta orang tua sangat dibutuhkan karena orang tua adalah subyek pertama yang perilakunya diidentifikasi, diinternalisasi yang pada akhirnya akan menjadi bagian dari 
kepribadian anak. Kecerdasan emosi ini dapat diajarkan pada saat anak masih bayi dengan contoh-contoh ekspresi. Kehidupan emosi yang dipupuk dalam keluarga sangat berguna bagi anak kelak di kemudian hari, sebagai contoh: melatih kebiasaan hidup disiplin dan bertanggung jawab, kemampuan berempati, kepedulian, dan sebagainya. Hal ini akan menjadikan anak menjadi lebih mudah untuk menangani dan menenangkan diri dalam menghadapi permasalahan, sehingga anak-anak dapat berkonsentrasi dengan baik dan tidak memiliki banyak masalah tingkah laku seperti tingkah laku kasar dan negatif.

\section{Kedua Lingkungan non keluarga.}

Dalam hal ini adalah lingkungan masyarakat dan lingkungan penduduk. Kecerdasan emosi ini berkembang sejalan dengan perkembangan fisik dan mental anak. Pembelajaran ini biasanya ditunjukkan dalam aktivitas bermain anak seperti bermain peran. Anak berperan sebagai individu di luar dirinya dengan emosi yang menyertainya sehingga anak akan mulai belajar mengerti keadaan orang lain. Pengembangan kecerdasan emosi dapat ditingkatkan melalui berbagai macam bentuk pelatihan diantaranya adalah pelatihan asertivitas, empati dan masih banyak lagi bentuk pelatihan yang lainnya.

Menurut Goleman (2002) faktor-faktor yang mempengaruhi kecerdasan emosi antara lain: pertama secara fisik bagian yang paling menentukan atau paling berpengaruh terhadap kecerdasan emosi seseorang adalah anatomi saraf emosinya. Bagian otak yang digunakan untuk berfikir yaitu konteks (kadang disebut juga neo konteks). Konteks khusus lobus prefrontal, dapat bertindak sebagai saklar peredam yang memberi arti terhadap situasi emosi sebelum berbuat sesuatu. Bagian ini sering disebut sebagai emosi otak yang letaknya jauh di dalam hemisfer otak besar dan terutama bertanggung jawab atas pengaturan emosi dan impuls. Kedua psikis Kecerdasan emosi selain dipengaruhi oleh kepribadian individu, juga dapat dipupuk dan diperkuat dalam diri individu itu. Terdapat dua faktor yang dapat mempengaruhi kecerdasan emosi seseorang yaitu secara fisik dan psikis. Secara fisik terletak di bagian otak yaitu konteks, secara psikis terletak pada kepribadian individu yang dipengaruhi oleh lingkungan keluarga dan lingkungan non keluarga.

\section{Independensi Auditor}

Pada umumnya independensi merupakan sifat seorang auditor yang tidak dapat dipengaruhi oleh siapapun dalam melaksanakan pekerjaannya sebagai seorang auditor dalam mengaudit laporan keuangan untuk kepentingan umum. Menurut Mulyadi (2002) mengatakan bahwa "Independensi adalah sikap mental yang bebas dari pengaruh, tidak dikendalikan oleh pihak lain,tidak tergantung pada orang lain. Independensi juga berarti adanya kejujuran dalam diri auditor dalam mempertimbangkan fakta dan adanya pertimbangan yang objektif tidak memihak dalam diri auditor dalam merumuskan dan menyatakan pendapatnya".

Auditor dalam kenyataannya seringkali menemui kesulitan dalam mempertahankan sikap mental independen. Keadaan yang seringkali mengganggu sikap mental independen auditor adalah seperti yang dikemukakan oleh Mulyadi (2002): (1) Sebagai seorang yang melaksanakan audit secara independen, auditor dibayar oleh kliennya atas jasanya tersebut. (2) Sebagai penjual jasa seringkali auditor mempunyai kecenderungan untuk memuaskan keinginan kliennya. (3) Mempertahankan sikap mental independen seringkali dapat menyebabkan lepasnya klien.

Mulyadi (2002) mengatakan bahwa faktor yang dapat mempengaruhi independensi akuntan publik beberapa diantaranya adalah (1) hubungan keuangan dengan klien, kedudukan dalam perusahaan, (2) keterlibatan dalam usaha yang tidak sesuai dengan klien dan tidak konsisten, (3) pelaksanaan jasa lain untuk klien audit, (4) hubungan keluarga dan pribadi, imbalan atas jasa profesional, (5) penerimaan barang atau jasa dari klien, (6) pemberian barang atau jasa kepada klien. Sementara dalam penelitian Alim dkk (2007) 
mengindikasi terdapat lima indikator penilaian independensi auditor yaitu (1) lama penugasan audit, (2) pengungkapan kecurangan audite, (3) besarnya fee audit, (4) pemberian fasilitas dari audite, (5) penggantian auditor, dan (6) penggunaan jasa non audit Sedangkan dalam penelitian ini indikator-indikator yang akan diteliti adalah lama hubungan dengan klien, tekanan dari klien, audit fee dan profil dari kantor akuntan publik, Pemilihan keempat indikator tersebut disebabkan karena dari semua indikator-indikator yang dapat mempengaruhi independensi akuntan publik, keempat indikator tersebut paling dominan dan dalam kenyataannya sering menjadi masalah bagi kantor akuntan publik, klien maupun pihak ketiga pengguna laporan keuangan klien.

\section{Profesionalisme Auditor}

Dalam pengertian umum, seseorang dikatakan profesional jika memenuhi tiga kriteria, yaitu mempunyai keahlian untuk melaksanakan tugas sesuai dengan bidangnya, melaksanakan suatu tugas atau profesi dengan menetapkan standar baku di bidang profesi yang bersangkutan dan menjalankan tugas profesinya dengan mematuhi etika profesi yang telah ditetapkan. Dalam penelitian ini konsep profesionalisme yang digunakan adalah konsep untuk mengukur bagaimana para profesional memandang profesi merekayang tercermin dalam sikap dan perilaku mereka. Menurut Lekatompessy (2009) dalam Kirana (2012) mendefinisikan profesionalisme adalah:

"Profesionalisme dapat dibedakan secara konseptual, profesi merupakan jenis pekerjaan yang memenuhi beberapa kriteria, sedangkan profesionalisme merupakan atribut individual yang penting tanpa melihat apakah suatu pekerjaan merupakan suatu profesi atau tidak". Taksonomi profesionalisme Hall digunakan untuk menguji profesionalisme para akuntan publik Morrow dan Goetz, 1988 dalam Anwar (2007). Konsep profesionalisme yang dikembangkan oleh Hall R (1968) dalam Herawati (2009) adalah konsep profesionalisme meliputi lima dimensi:

Pertama pengabdian pada profesi (Dedication to the profession), yang tercermin dalam dedikasi profesional melalui penggunaan pengetahuan dan kecakapan yang dimiliki. Sikap ini adalah ekspresi dari penyerahan diri secara total terhadap pekerjaan. Pekerjaan didefinisikan sebagai tujuan hidup dan bukan sekadar sebagai alat untuk mencapai tujuan. Penyerahan diri secara total merupakan komitmen pribadi, dan sebagai kompensasi utama yang diharapkan adalah kepuasan rohaniah dan kemudian kepuasan material.

Kedua kewajiban sosial (social obligation), yaitu pandangan tentang pentingnya peran profesi serta manfaat yang diperoleh baik oleh masyarakat ataupun oleh profesional karena adanya pekerjaan tersebut.

Ketiga kemandirian (Demands for autonomy), yaitu suatu pandangan bahwa seorang profesional harus mampu membuat keputusan sendiri tanpa tekanan dari pihak yang lain.

Keempat keyakinan terhadap peraturan profesi (belief in self-regulation), yaitu suatu keyakinan bahwa yang berwenang untuk menilai pekerjaan profesional adalah rekan sesama profesi, dan bukan pihak luar yang tidak mempunyai kompetensi dalam bidang ilmu dan pekerjaan mereka.

Kelima hubungan dengan sesama profesi (professional community affiliation), berarti menggunakan ikatan profesi sebagai acuan, termasuk organisasi formal dan kelompok kolega informal sebagai sumber ide utama pekerjaan. Melalui ikatan profesi ini para profesional membangun kesadaran profesinya.

Kelima dimensi tersebut dideskripsikan sebagai dedikasi terhadap profesi, kewajiban sosial, tuntutan otonomi personal, percaya pada peraturan profesi sendiri dan afiliasi komunitas. Setiap dimensi pada lima dimensi profesionalisme memiliki manfaat untuk menjelaskan profesionalisme dalam hubungannya dengan auditor. 


\section{Pengambilan Keputusan Auditor}

Menurut Arens (2004) mengatakan bahwa keputusan auditor adalah merupakan suatu proses yang tersusun baik dalam memutuskan laporan audit apa yang tepat untuk diterbitkan pada serangkaian kondisi tertentu. Pertama-tama auditor harus memberikan penelitian mengenai apakah terdapat kondisi yang menyebabkannya menerbitkan laporan audit di luar laporan audit berbentuk baku. Jika memang terdapat kondisi yang dimaksud, auditor kemudian harus menilai tingkat materialitas dari kondisi tersebut dan menentukan jenis laporan audit yang tepat.

\section{METODE PENELITIAN}

Analisis data yang digunakan adalah analisis regresi linier berganda dan determinasi karena penelitian ini menguji pengaruh kecerdasan emosional, indepndensi, dan profesionalisme auditor terhadap pengambilan keputusan pada Kantor Akuntan Publik (KAP) Padang. Populasi dalam penelitian ini adalah auditor independen yang bekerja pada Kantor Akuntan Publik (KAP) Padang, meliputi seluruh staf auditor baik auditor senior maupun junior yang ada pada Kantor Akuntan Publik (KAP) di Padang. Di mana ada 6 kantor akuntan publik, auditor sebanyak 37 orang yang terdiri dari 4 Kantor Akuntan Publik (KAP) (Arikunto, 2006).

\section{Kecerdasan Emosional $\left(\mathbf{X}_{1}\right)$}

Menurut Goleman (2002) "Kecerdasan emosi merupakan kemampuan emosi yang meliputi kemampuan untuk mengendalikan diri, memiliki daya tahan ketika menghadapi suatu masalah, mampu mengendalikan impuls, memotivasi diri, mampu mengatur suasana hati, kemampuan berempati dan membina hubungan dengan orang lain". Pada penelitian ini X1 akan diproksikan dengan 5 sub variabel yaitu: Mengenali emosi diri, Mengelola emosi, Memotivasi diri sendiri, empati, Membina hubungan.

\section{Independensi Auditor $\left(\mathrm{X}_{2}\right)$}

Independensi $\left(\mathrm{X}_{2}\right)$ adalah sikap yang diharapkan dari seorang akuntan publik untuk tidak mempunyai kepentingan pribadi dalam melaksanakan tugasnya, yang bertentangan dengan prinsip integritas dan objektivitas. Oleh karena itu pada penelitian ini variabel Independensi akan diproksikan dengan 4 sub variabel lama hubungan dengan klien, tekanan dari klien, audit fee dan profil dari kantor akuntan publik

\section{Profesionalisme Auditor ( $\left.\mathbf{X}_{3}\right)$}

Profesionalisme adalah kemampuan, keahlian, dan komitmen profesi dalam menjalankan tugas. Akuntan yang profesional dalam melaksanakan pemeriksaan diharapkan akan menghasilkan audit yang memenuhi standar yang telah ditetapkan sesuai dengan kode etik dan standar profesi.

Untuk menguji profesionalisme para akuntan publik Morrow dan Goetz (1988) dalam Anwar (2007). Konsep profesionalisme yang dikembangkan oleh Hall R. adalah konsep profesionalisme yang meliputi lima dimensi: Pengabdian pada profesi (Dedication to the profession), Kewajiban sosial (social obligation), Kemandirian (Demands for autonomy), Keyakinan terhadap peraturan profesi (belief in self-regulation), Hubungan dengan sesama profesi (professional community affiliation).

\section{Pengambilan Keputusan (Y)}

Menurut Arens dalam Yanti, (2013) mengatakan bahwa keputusan auditor adalah merupakan suatu proses yang tersusun baik dalam memutuskan laporan audit apa yang tepat untuk diterbitkan pada serangkaian kondisi tertentu. Pada penelitian ini variabel Y akan diproksikan dengan 4 sub variabel yaitu: Laporan Audit Bentuk Baku, 
Penyimpangan dari Laporan Audit Bentuk baku, Menentukan Tingkat Materialitas, Menuliskan laporan Audit

Setiap butir kuesoner masin-masing variabel bentuk kalimat pertanyaan atau peryataan yang terdiri dari 5 kemungkinan jawaban dengan skor atau nilai yang diberi bobot masing-masing menurut likert dalam Sugiyono (2003) sebagai berikut:
1. Jawab Sangat Setuju (SS)
: nilai skala/bobot 5
2. Jawab setuju $(\mathrm{S})$
: nilai skala/bobot 4
3. Jawab kurang setuju (KS)
: nilai skala/bobot 3
4. Jawaban tidak setuju (TS)
: nilai skala/bobot 1
5. Jawaban sangat tidak setuju (STS)
: nilai skala/bobot 0

\section{HASIL PENELITIAN}

\section{Deskripsi Identitas Responden}

Deskripsi responden yang berisi tentang jenis kelamin responden, pendidikan terakhir responden, lama bekerja responden, dan jumlah klien yang telah di audit oleh responden selama tahun 2013 sampai 2014.

1. Krakteristik Responden berdasarkan Jenis Gender

Kerakteristik responden auditor di Padang berdasarkan jenis Gender dapat dilihat dalam tabel 4.1

Tabel 4.1 Karakteristi Berdasarkan Gender

\begin{tabular}{lcc}
\hline Jenis Kelamin & Jumlah (Orang) & Prosentasi (\%) \\
\hline Laki-laki & 16 & 43.2 \\
\hline Perempuan & 21 & 56.8 \\
\hline \multicolumn{1}{c}{ Jumlah } & 37 & 100.0 \\
\hline
\end{tabular}

Berdasarkan pada tabel 4.1 di atas teridentifikasi sebanyak 37 responden yang menjadi sampel dalam penelitian ini, terlihat sebanyak 16 orang responden atau sebesar 43,2 \% yang berjenis kelamin laki-laki dan sisanya sebanyak 21 orang responden atau 56,8 $\%$ berjenis kelamin perempuan. Dengan demikian dapat disimpulkan bahwa sebagian besar auditor yang bekerja di Kantor Akuntan Publik lebih didominasi oleh perempuan.

2. Karakteristik Responden Berdasarkan Jenjang pendidikan

Tabel 4.2 Karakteristik Berdasarkan Jenjang Pendidikan

\begin{tabular}{lcc}
\hline Pendidikan & Jumlah (Orang) & Prosentasi (\%) \\
\hline D III & 8 & 21.6 \\
\hline S 1 & 29 & 78.4 \\
\hline Jumlah & 35 & 100.0 \\
\hline
\end{tabular}

Dari tabel 4.2 di atas dapat disimpulkan bahwa responden auditor di Padang dominan jenjang pendidikan yaitu sebanyak 29 orang pendidikan S1 atau sebesar 78,4 \% dan DIII sebanyak 8 orang atau sebesar $21,6 \%$.

3. Karakteristik Responden Berdasarkan Masa Kerja

Karakteristik responden berdasarkan masa akerja auditor di Padang dilihat berdasarkan lama bekerja di kantor Akuntan Publik Padang dapat dilihat dalam tabel berikut:

Tabel 4.3 Karakteristik Berdasarkan Masa Kerja 


\begin{tabular}{|l|c|c|}
\hline Lama bekerja & Jumlah & \% \\
\hline 1 sampai 2 tahun & 19 & 51.4 \\
\hline 2 sampai 3 tahun & 8 & 21.6 \\
\hline 3 sampai 4 tahun & 6 & 16.2 \\
\hline 4 tahun & 4 & 10.8 \\
\hline Jumlah & 37 & 100.0 \\
\hline
\end{tabular}

Dari tabel di atas dapat disimpulkan bahwa responden yang memiliki masa kerja 12 tahun sebanyak 19 orang atau sebesar 51,4\%. Yang memiliki masa kerja 2-3 tahun sebanyak 8 orang atau sebesar 21,6\%, masa kerja $3-4$ tahun sebanyak 6 orang atau sebesar $16,2 \%$, dan yang memiliki masa kerja> 4 tahun sebanyak 4 orang atau sebesar 10,8\%. Dapat disimpulkan bahwa masa kerja auditor yang bekerja di Kantor akuntan Publik di Padang lebih didominasi 1 s/d 2 tahun masa kerja.

4. Kerakteristik responden berdasarkan jumlah klien yang diaudit oleh auditor di Padang selama tahun 2013 dan 2014

Tabel 4.4 Karakteristik Berdasarkan Klien yang di Audit selama tahun 2013 dan 2014

\begin{tabular}{|l|c|c|}
\hline Lama bekerja & Jumlah & \% \\
\hline 1 sampai 2 tahun & 20 & 54.1 \\
\hline 2 sampai 3 tahun & 8 & 21.6 \\
\hline 3 sampai 4 tahun & 5 & 13.5 \\
\hline 4 tahun & 4 & 10.8 \\
\hline Jumlah & 37 & 100.0 \\
\hline
\end{tabular}

Berdasarkan tabel 4.4 di atas dapat disimpulkan bahwa jumlah klien yang diaudit oleh auditor yang terdiri dari 1-3 klien sebanyak 20 orang atau sebesar 54,1\%, 4-6 klien sebanyak 8 orang atau sebesar 21,6\%,7-10 klien sebanyak 5 orang atau sebesar 13,5\%, sedangkan $>10$ klien sebanyak 4 orang atau sebesar $10,8 \%$.

\section{Uji Kualitas Data \\ Uji Validitas}

\section{Kecerdasan Emosional}

Hasil uji validitas kecerdasan emosional terlihat dari 15 item pertanyaan yang digunakan untuk mengukur kecerdasan emosional valid, hasil perolehan tersebut menunjukkan bahwa masing-masing item pertanyaan yang valid memiliki nilai Corrected Item-Total Correlation di atas 0.30, maka dapat disimpulkan bahwa masing-masing item pertanyaan ini dapat terus digunakan ke dalam tahapan pengolahan data selanjutnya.

\section{Independensi Auditor}

Tabel 4.5 Pengujian Validitas Independensi Auditor

\begin{tabular}{|c|c|c|c|}
\hline No & Item Pertanyaan & Corrected Item-Total Correlation & Keterangan \\
\hline 1 & $\mathrm{X}_{2 .} 1$ & 0.834 & Valid \\
\hline 2 & $\mathrm{X}_{2 .} 2$ & 0.425 & Valid \\
\hline 3 & $\mathrm{X}_{2 .} 3$ & 0.590 & Valid \\
\hline 4 & $\mathrm{X}_{2 .} 4$ & 0.594 & Valid \\
\hline 5 & $\mathrm{X}_{2 .} 5$ & 0.364 & Valid \\
\hline 6 & $\mathrm{X}_{2 .} 6$ & 0.607 & Valid \\
\hline 7 & $\mathrm{X}_{2 .}$. & 0.751 & Valid \\
\hline 8 & $\mathrm{X}_{2 .} 8$ & 0.374 & Valid \\
\hline 9 & $\mathrm{X}_{2 .} 9$ & 0.308 & Valid \\
\hline
\end{tabular}


Berdasarkan tabel 4.5 dari hasil pengujian validitas dapat dilihat bahwa nilai corrected item-total correlation semua item pertanyaan berkisar antara 0,834 - 0,307 atau dengan kata lain memiliki nilai corrected item-total correlation lebih besar dari 0,30. Dengan demikian dapat disimpulkan bahwa 9 item pertanyaan tersebut dinyatakan valid.

\section{Prefesionalisme Auditor}

Tabel 4.6 Pengujian Validitas Profesionalisme Auditor

\begin{tabular}{|c|c|c|c|}
\hline No & Item Pertanyaan & Corrected Item-Total Correlation & Keterangan \\
\hline 1 & $\mathrm{X}_{3.1}$ & 0.829 & Valid \\
\hline 2 & $\mathrm{X}_{3.2}$ & 0.308 & Valid \\
\hline 3 & $\mathrm{X}_{3.3}$ & 0.337 & Valid \\
\hline 4 & $\mathrm{X}_{3.4}$ & 0.792 & Valid \\
\hline 5 & $\mathrm{X}_{3.5}$ & 0.887 & Valid \\
\hline 6 & $\mathrm{X}_{3 .} 6$ & 0.904 & Valid \\
\hline 7 & $\mathrm{X}_{3 .}$ & 0.836 & Valid \\
\hline 8 & $\mathrm{X}_{3 .} 8$ & 0.669 & Valid \\
\hline 9 & $\mathrm{X}_{3 .}$ & 0.307 & Valid \\
\hline 10 & $\mathrm{X}_{3 .} 10$ & 0.769 & Valid \\
\hline 11 & $\mathrm{X}_{3.1}$ & 0.365 & Valid \\
\hline 12 & $\mathrm{X}_{3 .} 12$ & 0.963 & Valid \\
\hline 13 & $\mathrm{X}_{3.13}$ & 0.904 & Valid \\
\hline 14 & $\mathrm{X}_{3 .} 14$ & 0.811 & Valid \\
\hline 15 & $\mathrm{X}_{3 .} 15$ & 0.566 & Valid \\
\hline 16 & $\mathrm{X}_{3.16}$ & 0.528 & Valid \\
\hline
\end{tabular}

Berdasarkan tabel 4.6 dari hasil pengujian validitas dapat dilihat bahwa nilai corrected item-total correlation semua item pertanyaan berkisar antara 0,963 - 0,307 atau dengan kata lain memiliki nilai corrected item-total correlation lebih besar dari 0,30. Dengan demikian dapat disimpulkan bahwa 16 item pertanyaan tersebut dinyatakan valid.

\section{Pengambilan Keputusan auditor}

Tabel 4.7 Pengujian Validitas Pengambilan Auditor

\begin{tabular}{|c|c|c|c|}
\hline No & Item Pertanyaan & Corrected Item-Total Correlation & Keterangan \\
\hline 1 & Y. 1 & 0.545 & Valid \\
\hline 2 & Y. 2 & 0.391 & Valid \\
\hline 3 & Y.3 & 0.518 & Valid \\
\hline 4 & Y.4 & 0.495 & Valid \\
\hline 5 & Y.5 & 0.535 & Valid \\
\hline 6 & Y.6 & 0.648 & Valid \\
\hline 7 & Y.7 & 0.484 & Valid \\
\hline 8 & Y. & 0.495 & Valid \\
\hline 9 & Y.9 & 0.769 & Valid \\
\hline 10 & Y.10 & 0.818 & Valid \\
\hline 11 & Y.11 & 0.789 & Valid \\
\hline 12 & Y.12 & 0.569 & Valid \\
\hline
\end{tabular}

Berdasarkan pada tabel 4.7 terlihat 12 item pertanyaan untuk mengukur pengambilan keputusan auditor memiliki nilai corrected item-total correlation lebih besar dari 0,30. Dapat disimpulkan bahwa pengujian validitas pada variabel ini yaitu semua item pertanyaan dinyatakan valid dan item pertanyaan berkisar antara 0,818 - 0,391. 


\section{Pengujian Reliabilitas}

Tabel 4.7 Hasil Pengujian Reliabilitas

\begin{tabular}{|c|c|c|c|}
\hline Variabel & Item Pertanyaan & Cronbach Alpha & Ket \\
\hline $\mathrm{X}_{1}$ & 15 & 0.871 & Reliabel \\
\hline $\mathrm{X}_{2}$ & 9 & 0.814 & Reliabel \\
\hline $\mathrm{X}_{3}$ & 16 & 0.941 & Reliabel \\
\hline $\mathrm{Y}$ & 12 & 0.869 & Reliabel \\
\hline
\end{tabular}

Pada tabel 4.7 terlihat hasil pengujian reliabilitas data untuk semua variabel yang digunakan dalam penelitian ini memiliki nilai Cronbach Alpha di atas 0,70. Variabel kecerdasan emosional $\left(\mathrm{X}_{1}\right)$ memiliki Cronbach Alpha sebesar 0,871, variabel independensi auditor $\left(\mathrm{X}_{2}\right)$ memiliki Cronbach Alpha sebesar 0,814, dan variabel Profesionalisme auditor $\left(\mathrm{X}_{3}\right)$ memiliki Cronbach Alpha sebesar 0,941, variabe Pengambilan keputusan (Y)1 memiliki Cronbach Alpha sebesar 0,869. Dapat disimpulkan bahwa semua variabel yang digunakan dalam penelitian ini dikatakan reliabel atau handal.

\section{Uji Asumsi Klasik Uji Normalitas}

Tabel 4.8 Hasil Pengujian Normalitas

\begin{tabular}{|c|c|c|c|c|}
\hline No & Variabel & Asymp Sig(2-Tailed) & Alpha & Keterangan \\
\hline 1 & $\mathrm{X}_{1}$ & 0,700 & 0,05 & Normal \\
\hline 2 & $\mathrm{X}_{2}$ & 0,168 & 0,05 & Normal \\
\hline 3 & $\mathrm{X}_{3}$ & 0,227 & 0,05 & Normal \\
\hline 4 & $\mathrm{Y}$ & 0,244 & 0,05 & Normal \\
\hline
\end{tabular}

Pada tabel 4.8terlihat bahwa masing-masing variabel penelitian yang digunakan pada penelitian ini memiliki nilai Asymp Sig (2-Tailed) di atas 0,05. Di mana diketahui bahwa signifikan untuk, variabel kecerdasan emosional $\left(\mathrm{X}_{1}\right)$ sebesar 0,700 , independensi auditor $\left(\mathrm{X}_{2}\right)$ sebesar 0,168 dan profesionalisme auditor $\left(\mathrm{X}_{3}\right)$ sebesar 0,227 , variabel pengambilan keputusan auditor (Y) sebesar 0,244. Dapat disimpulkan bahwa nilai signifikan variabelx dan y pada penelitian ini memiliki nilai signifikan lebih besar dari tingkat alpha 0,05 dan demikian dapat dikatakan semua variabel tersebut berdistribusi normal.

\section{Pengujian Multikolinearitas}

Tabel 4.9 Hasil Pengujian Multikolinearitas

\begin{tabular}{|c|c|c|c|}
\hline Variabel & Tolerance & VIF & Keterangan \\
\hline$X_{1}$ & 0,691 & 1,447 & Tidak Terjadi Multikolinearitas \\
\hline$X_{2}$ & 0,731 & 1,367 & Tidak Terjadi Multikolinearitas \\
\hline$X_{3}$ & 0,668 & 1,498 & Tidak Terjadi Multikolinearitas \\
\hline
\end{tabular}

Pada tabel 4.9 terlihat bahwa masing-masing variabel independen yang digunakan pada penelitian ini memiliki nilai tolerance di atas 0,10 atau nilai Variance Inflantion Factor yang dihasilkan berada dibawah 10. Dapat disimpulkan bahwa variabel independen yang terdiri dari kecerdasan emosional, independensi, dan profesionalisme yang digunakan pada penelitian ini terbebas dari gejala multikolinearitas dan tahapan pengolahan data selanjutnya dapat dilakukan. 


\section{Pengujian Heteroskedastisitas}

Tabel 4.10 Hasil Pengujian Heteroskedastisitas (Glejser Model)

\begin{tabular}{|c|c|c|c|}
\hline Variabel & Sig & Alpha & Keterangan \\
\hline $\mathrm{X}_{1}$ & 0.219 & 0,05 & Tidak Terjadi Heteroskedastisitas \\
\hline $\mathrm{X}_{2}$ & 0,777 & 0,05 & Tidak Terjadi Heteroskedastisitas \\
\hline $\mathrm{X}_{3}$ & 0,223 & 0,05 & Tidak Terjadi heteroskedastisitas \\
\hline
\end{tabular}

Berdasarkan tabel 4.10 terlihat bahwa masing-masing variabel independen yang digunakan pada penelitian ini memiliki nilai signifikan di atas 0,05. Dapat disimpulkan dari hasil yang diperoleh menunjukkan masing-masing variabel independen terbebas dari gejala heteroskedastisitas

\section{Analisi Regresi Linier Berganda}

Tabel 4.11 Hasil Regresi Linier Berganda

\begin{tabular}{|c|c|c|c|c|c|}
\hline Variabel & Koefisien Regresi & Term Eror & Sig t & Alpha & Keterangan \\
\hline Constant & 0.991 & 0.778 & - & - & - \\
\hline $\mathrm{X}_{1}$ & 0.379 & 0.219 & 0.094 & 0,05 & Tidak Signifikan \\
\hline $\mathrm{X}_{2}$ & -0.097 & 0.149 & 0.519 & 0,05 & Tidak Signifikan \\
\hline $\mathrm{X}_{3}$ & 0.526 & 0.189 & 0.009 & 0,05 & Signifikan \\
\hline
\end{tabular}

Berdasarkan pada tabel 4.11 terlihat bahwa masing-masing variabel penelitian yang digunakan pada penelitian ini dapat dibuat ke dalam sebuah persamaan regresi berganda seperti di bawah ini:

$$
\mathrm{Y}=0,991+0,379 \times 1-0,097 \times 2+0,526 \times 3+e
$$

Maka dari hasil persamaan regresi di atas dapat disimpulkan bahwa nilai konstanta adalah 0,991 , variabel $X_{1}$ diperoleh nilai koefisien regresi bertanda positif sebesar 0,379 , variabel $\mathrm{X}_{2}$ diperoleh nilai koefisien regresi bertanda negatif sebesar - 0,097, dan variabel $\mathrm{X}_{3}$ diperoleh nilai koefisien regresi bertanda positif sebesar 0,526.

\section{Pengujian Hipotesis Uji t- statistik}

\begin{tabular}{|c|c|c|c|c|c|}
\hline Variabel & Koefisien Regresi & Term Eror & Sig t & Alpha & Keterangan \\
\hline Constant & 0.991 & 0.778 & - & - & - \\
\hline $\mathrm{X}_{1}$ & 0.379 & 0.219 & 0.094 & 0,05 & Tidak Signifikan \\
\hline $\mathrm{X}_{2}$ & -0.097 & 0.149 & 0.519 & 0,05 & Tidak Signifikan \\
\hline $\mathrm{X}_{3}$ & 0.526 & 0.189 & 0.009 & 0,05 & Signifikan \\
\hline
\end{tabular}

Berdasarkan tabel 4.12 di atas variabel kecerdasan emosional menghasilkan nilai t sig sebesar 0,94 sedangkan alpha sebesar 0,05. Sehingga dapat disimpulkan bahwa hipotesis pertama Ho diterima $\mathrm{H}_{\mathrm{a}}$ ditolak berarti secara parsial kecerdasan emosional tidak berpengaruh terhadap pengambilan keputusan.

Pada variabel independensi auditor diperoleh t sig sebesar 0,519 sedangkan alpha 0,05.Sehingga dapat disimpulkan bahwa hipotesis pertama Ho diterima $\mathrm{H}_{\mathrm{a}}$ ditolak berarti secara parsial independensi tidak berpengaruh terhadap pengambilan keputusan. 
Pada variabel profesionalisme auditor nilai t sig 0,009 sedangkan alpha 0,05 Sehingga dapat disimpulkan bahwa hipotesis pertama $\mathrm{Ho}$ ditolak $\mathrm{H}_{\mathrm{a}}$ diterima berarti secara parsial independensi berpengaruh signifikan terhadap pengambilan keputusan.

Jadi dapat disimpulkan bahwa, variabel kecerdasan emosional, independensi, tidak berpengaruh terhadap pengambilan keputusan, sedangkan variabel profesionalisme berpengaruh signifikan terhadap pengambilan keputusan karena memiliki nilai t sig 0,009 $<$ alpha 0,05 .

\section{Pengujian F-Statistik}

Tabel 4.13 Pengujian F-statistik

\begin{tabular}{cccc}
\hline Variabel & Sig t & Alpha & Keterangan \\
\hline$X_{1}, X_{2,}, X_{3}$ & 0,001 & 0,05 & Signifikan \\
\hline
\end{tabular}

Berdasarkan tabel 4.15 dapat dilihat bahwa hasil pengujian F-statistik diperoleh nilai signifikan sebesar 0,001 . Pada pengolahan data digunakan tingkat kesalahan sebesar 0,05 (Imam, 2011), hasil yang diperoleh menunjukkan bahwa nilai signifikan sebesar $0,001<0,05$ maka dapat disimpulkan Ho di tolak dan Ha diterima sehingga dapat disimpulkan bahwa Kecerdasan emosional, independensi, dan Profesionalisme secara bersama-sama berpengaruh signifikan terhadap pengambilan keputusan.

\section{PEMBAHASAN}

\section{Pengaruh Kecerdasan Emosional terhadap Pengambilan Keputusan Auditor}

Berdasarkan pada pengujian hipotesis pertama yang bertujuan untuk mengetahui Pengaruh Kecerdasan Emosional terhadap Pengambilan Keputusan Auditor pada Kantor Akuntan Publik Padang, diperoleh nilai koefisien regresi bertanda posistif sebesar 0,379 Pada tahapan pengolahan data juga diperoleh nilai signifikan sebesar 0,094. Proses pengolahan data dilaksanakan dengan tingkat kesalahan 0,05. Hasil yang diperoleh tersebut menunjukkan bahwa nilai signifikan sebesar 0,094> alpha 0,05 maka keputusannya adalah Ho diterima dan $\mathrm{H}_{1}$ ditolak sehingga dapat disimpulkan bahwa kecerdasan emosional tidak berpengaruh positif terhadap pengambilan keputusan auditor pada Kantor Akuntan Publik Padang.

Dalam penelitian ini variabel kecerdasan emosional tidak memberikan pengaruh positif terhadap pengambilan keputusan auditor karena auditor beranggapan bahwa mereka mampu mengendalikan diri, memiliki daya tahan ketika menghadapi masalah, sehingga hal ini tidak mempengaruhi mereka dalam mengambil keputusan.

\section{Pengaruh Independensi terhadap Pengambilan Keputusan Auditor}

Berdasarkan pada pengujian hipotesis kedua yang bertujuan untuk mengetahui independensi terhadap Pengambilan Keputusan Auditor pada Kantor Akuntan Publik Padang, diperoleh nilai koefisien regresi bertanda negatif sebesar -0,097 Pada tahapan pengolahan data juga diperoleh nilai signifikan sebesar 0,519. Proses pengolahan data dilaksanakan dengan tingkat kesalahan 0,05 . Hasil yang diperoleh tersebut menunjukkan bahwa nilai signifikan sebesar 0,519 > alpha 0,05 maka keputusannya adalah Ho diterima dan $\mathrm{H}_{2}$ ditolak sehingga dapat disimpulkan bahwa independensi tidak berpengaruh bertanda negatif terhadap pengambilan keputusan auditor pada Kantor Akuntan Publik Padang.

\section{Pengaruh Profesionalisme terhadap Pengambilan Keputusan Auditor}

Berdasarkan pada pengujian hipotesis ketiga yang bertujuan untuk mengetahui profesionalisme terhadap pengambilan keputusan auditor pada Kantor Akuntan Publik Padang, diperoleh nilai koefisien regresi bertanda posistif sebesar 0,526 Pada tahapan 
pengolahan data juga diperoleh nilai signifikan sebesar 0,009. Proses pengolahan data dilaksanakan dengan tingkat kesalahan 0,05 . Hasil yang diperoleh tersebut menunjukkan bahwa nilai signifikan sebesar $0,009<$ alpha 0,05 maka keputusannya adalah Ho ditolak dan $\mathrm{H}_{3}$ diterima sehingga dapat disimpulkan bahwa profesionalisme berpengaruh positif terhadap pengambilan keputusan auditor pada Kantor Akuntan Publik Padang.

Dalam penelitian ini variabel profesionalisme memberikan pengaruh positif terhadap pengambilan keputusan auditor karena auditor beranggapan bahwa semakin profesional seseorang maka semakin baik dalam mengambil suatu keputusan.

\section{Pengaruh Kecerdasan Emosional, Independensi, dan Profesionalisme terhadap Pengambilan Keputusan Auditor}

Dari hasil penelitian secara uji F- statistik (simultan) ditemukan bahwa Kecerdasan Emosional, Independensi, dan Profesionalisme Pengaruh terhadap Pengambilan Keputusan Auditor pada Kantor Akuntan Publik di Padang. Hal ini ditemukan adanya nilai f sig sebesar $0,001<$ alpha 0,05 berarti Ho ditolak dan $\mathrm{H}_{\mathrm{a}}$ diterima sehingga dapat disimpulkan variabel independen secara bersama-sama berpengaruh signifikan terhadap variabel dependen.

\section{KESIMPULAN}

Berdasarkan analisis dan pembahasan hasil pengujian hipotesis yang dilakukan dapat disimpulkan dari penelitian ini antara lain:

Pertama hasil pengujian hipotesis pertama ditemukan kecerdasan emosional $\left(\mathrm{X}_{1}\right)$ tidak berpengaruh positif terhadap pengambilan keputusan auditor karena auditor beranggapan bahwa mereka mampu menggendalikan diri, memiliki daya tahan ketika menghadapi masalah, sehingga hal ini tidak mempengaruhi mereka dalam mengambil keputusan.

Kedua hasil pengujian Hipotesis kedua ditemukan bahwa independensi auditor $\left(\mathrm{X}_{2}\right)$ tidak berpengaruh bertanda negatif terhadap pengambilan keputusan auditor pada Kantor Akuntan Publik Padang

Ketiga hasil pengujian hipotesis ketiga ditemukan bahwa profesionalisme auditor $\left(\mathrm{X}_{3}\right)$ memberikan pengaruh positif terhadap pengambilan keputusan auditor karena auditor beranggapan bahwa semakin profesional seseorang maka semakin baik dalam mengambil suatu keputusan.

Keempat hasil pengujian hipotesis keempat ditemukan kecerdasan emosional, independensi, dan profesionalisme auditor berpengaruh signifikan terhadap terhadap pengambilan keputusan pada Kantor akuntan Publik Padang.

\section{DAFTAR PUSTAKA}

Agoes, S. (2004). Auditing (Pemeriksaan Akuntansi). Jakarta: Universitas Indonesia Anwar, C., \& Agustina, T. (2014). Pengaruh Profesionalisme Auditor Dan Komitmen Organisasi Terhadap Kinerja Internal Auditor. Jurnal Akuntansi dan Keuangan, $5(2)$

Alim, M. N., Hapsari, T., \& Purwanti, L. (2007). Pengaruh Kompetensi dan Independensi terhadap Kualitas Audit dengan Etika Auditor Sebagai Variabel Moderasi. Simposium Nasional Akuntansi X. UNHAS Makassar

Arens, A. A., Randal, J. E., \& Mark, S. B. (2004). Auditing dan Pelayanan Verifikasi, Pendekatan Terpadu. Jilid 1, Edisi Kesembilan. Penerbit PT. Indeks. Jakarta

Arikunto, S. (2006). Prosedur Penelitian Suatu Pendekatan (Edisi Revisi VI). Jakarta: PT Rineka Cipta

Choiriah, A. (2013). Pengaruh Kecerdasan Emosional, Kecerdasan Intelektual, Kecerdasan Spiritual Dan Etika Profesi Terhadap Kinerja Auditor Dalam Kantor Akuntan Publik. Jurnal Akuntansi, 1(1) 
Faisal, N., \& Yahya, M. R. (2012). Pengaruh Kompetensi, Independensi dan Profesionalisme terhadap Kualitas Audit dengan Kecerdasan Emosional sebagai Variabel Moderasi (Survei pada Kantor Akuntan Publik di Indonesia). Jurnal Akuntansi Pasca Sarjana Syiah Kuala, 1, 1-21

Goleman, D. (2002). Emitional Intelligence Kecerdasan Emosional Mengapa EQ Lebih Penting Daripada IQ. Jakata: PT Gramedia Pustaka Utama

Herawati, H., \& Susanto, S. (2009). Pengaruh Profesionalisme, Pengetahuan Mendeteksi Kekeliruan Dan Etika Profesi Terhadap Pertimbangan Tingkat Materialitas Akuntan Publik. Jurnal akuntansi dan keuangan. 11(1)

Herry, H. (2006). Pengaruh Pelaksanaan etika profesi, independensi, integritas dan objektivitas dalam pengambilan keputusan akuntan publik (auditor)

Imam, G. (2011). Analisis Multivariate dengan menggunakan SPSS 20.0. Semarang:

Badan Penerbit Universitas Diponegoro. Tanggal 5 Desember 2014

Indah, S. N., \& Pamudji, S. (2010). Pengaruh Kompetensi Dan Independensi Auditor Terhadap Kualitas Audit (Studi Empiris Pada Auditor Kap Di Semarang) (Doctoral dissertation, Universitas Diponegoro)

Keuangan, M. (2003). Keputusan Menteri Keuangan Nomor 423/KMK. 06/2002 jo 359/KMK. 06/2003 tentang "Jasa Akuntan Publik"

Kirana, A. L. (2012). Pengaruh Profesionalisme Auditor Terhadap Pertimbangan Tingkat Materialitas Laporan Keuangan (Pada Kantor Akuntan Publik Komisariat Wilayah Bandung). Universitas Komputer Indonesia

Kusuma, H. S., \& Kawedar, W. (2011). Pengaruh Pelaksanaan Etika Profesi Dan Kecerdasan Emosional Terhadap Pengambilan Keputusan Bagi Auditor (Studi Empiris da Kantor Akuntan Publik (KAP) dan Badan Pemeriksa Keuangan (BPK) di Semarang) Doctoral dissertation, Universitas Diponegoro)

Mulyadi, M. (2002). Auditing. Jakarta: Salemba Empat

Sugiyono, S. (2003). Metode Penelitian Bisnis. Cetakan kelima. Bandung: CV Alfabeta

Paulus, V, A., Rusmidin, M., Valensia ,E., Meliana, M., Sari, P., N. (2012, 20 Mei). Etika Profsi Audit. Tulisan pada http://captainvie.blogspot.com

Usvita, U. (2011). Pengaruh Kepuasan Nasabah, Keunggulan Produk, Citra Perusahaan terhadap Loyalitas Nasabah Tabungan Simpedes (Studi Kasus BRI Cabang Padang). Tesis. Universitas Bung Hatta

Wahyudi, F. (2016). Pengaruh Kecerdasan Emosional Terhadap Pengambilan Keputusan Bagi Auditor (Doctoral dissertation, Universitas Widyatama)

Yanti, A., M. (2013). Pengaruh Kompetensi Dan Independensi Auditor Terhadap Kualitas Audit (Studi Empiris Pada Kantor Akuntan Publik di Padang) 